\title{
Systemic Racism in Education: Perspectives of Teachers of Color
}

A culminating thesis submitted to the faculty of Dominican University of California in partial fulfilment of the requirements for the degree of Master of Science in Education.

Dominican University of California

San Rafael, CA

May 2020 
Copyright Stephany Vallejo 2020 All Right Reserved 


\begin{abstract}
Many strides have been made in addressing equity, diversity and social justice in the field of education. However there has remained a gap in the representation of the voices of Teachers of Color. Current literature reveals that there is underlying systemic racism deterring People of Color from pursuing a career in education for a variety of reasons including social, financial, racial and political barriers. Applying Critical Race Theory, critical studies of Whiteness and Microaggressions this study analyzes the experiences of Teachers of Color through their educational career. This research uses a qualitative methods approach with an emphasis on a constructivist worldview, and interviews with Teachers of Color were conducted across three campuses. Through the process of analyzing and interpreting the experiences of Teachers of Color, the findings emerged as a process of naming shared experiences; being Dismissed, Silenced, Censored, and becoming Exhausted in a Colorblind Workplace. Collectively, these findings can be used as a tool to further conversations concerning what deters People of Color from the field of education. This study proposes that in order to combat the lack of Teachers of Color, we need to talk and educate all stakeholders about their experiences.
\end{abstract}




\section{Acknowledgements}

For my mother, Carmen, who came from Mexico for a better life for herself and her future children, I thank you for always supporting me every step of the way. For my siblings, Jason, Katie, and Jaden, who have always pushed and challenged me to be the best big sister and being my inspiration for showing them anything is possible, I love you always. For my students thank you for inspiring me everyday to challenge the systemic racism in our learning environments to ensure that they have the best education. For all my past teachers who believed in me and challenged me to reach a potential I did not think possible, I appreciate that you saw things before I was able. For my mentors, who have supported me through my first year of teaching while I attempted a master's degree, I appreciate and celebrate the guidance you provided. And a special thanks to Matthew Davis and Emily Wu for guiding me through this process. 


\section{Table of Contents}

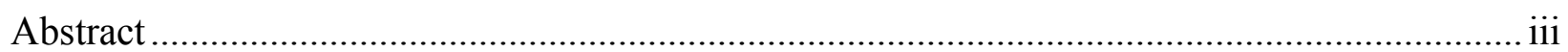

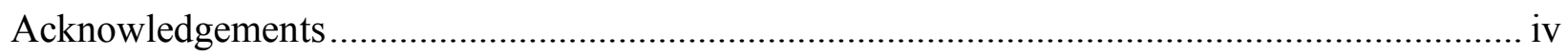

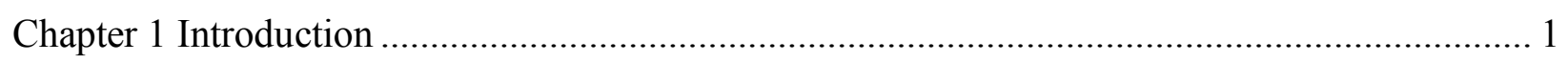

Statement of Purpose ................................................................................................ 2

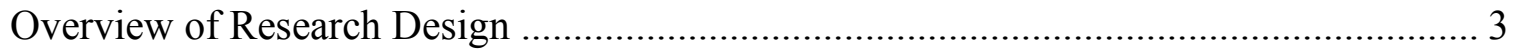

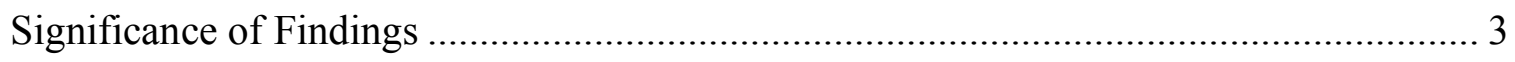

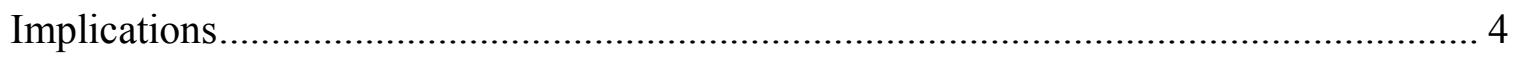

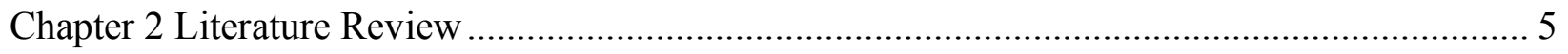

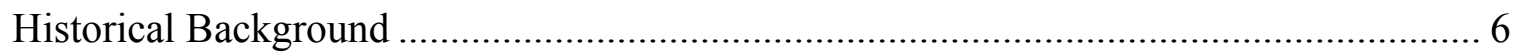

Systemic Racism in Education, HBCUs and the Exclusion of TOC's ............................ 7

Parallel Educational Barriers for Native Americans and Latinx .................................. 9

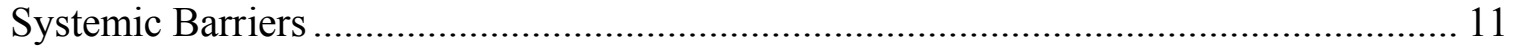

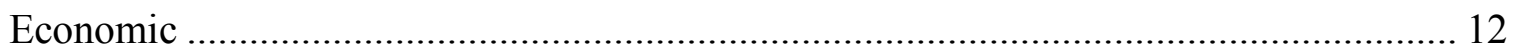

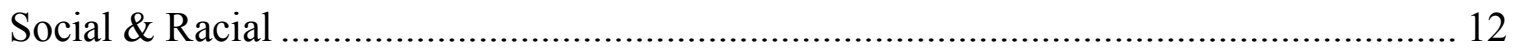

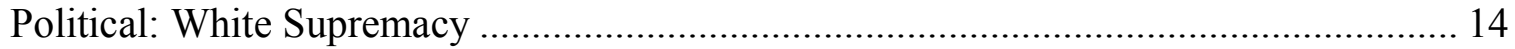

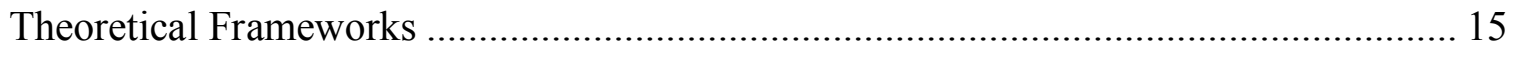

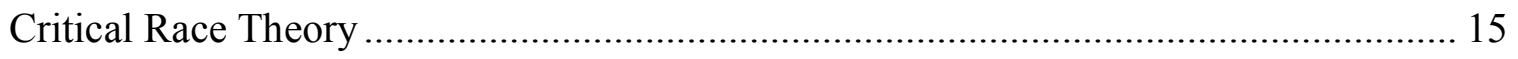

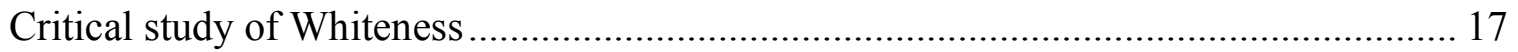

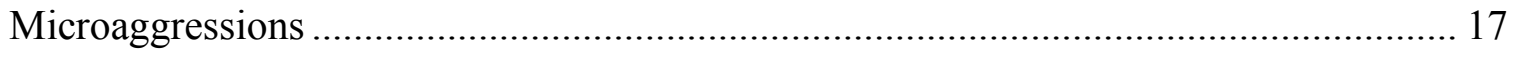

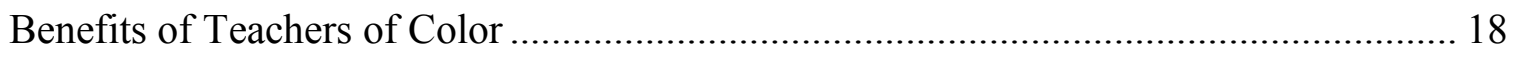

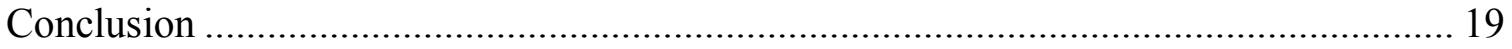

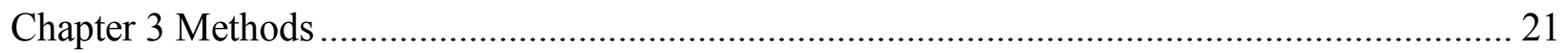

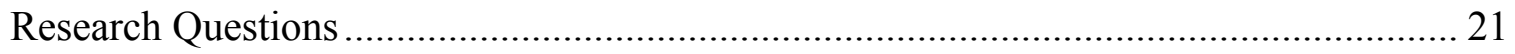




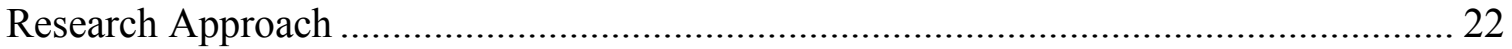

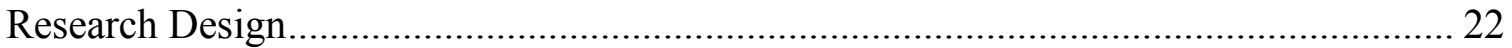

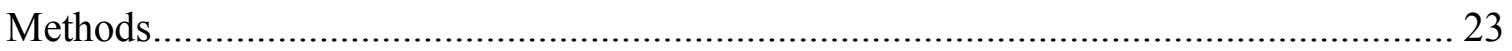

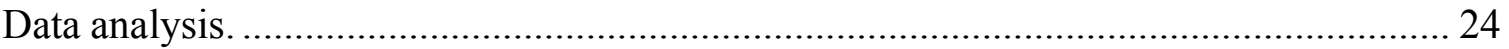

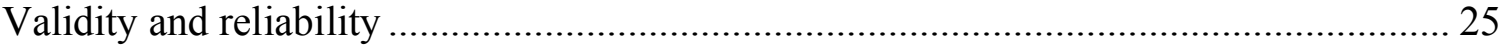

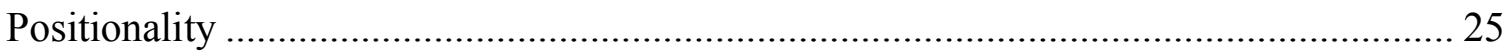

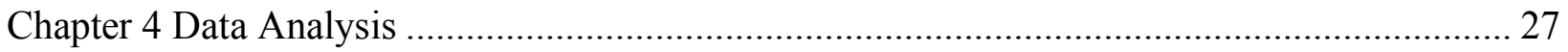

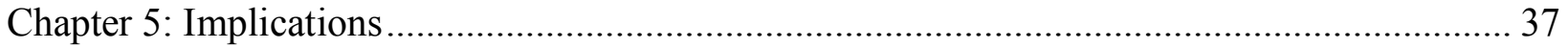

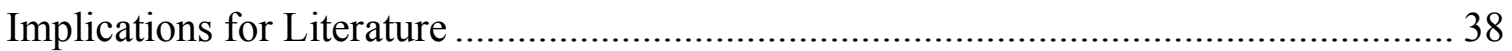

Implications for Practice and Policy ……………………………………………….... 39

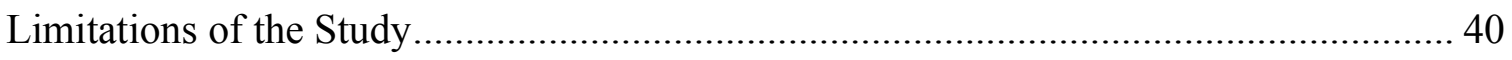

Implications for Future Research ................................................................................. 40

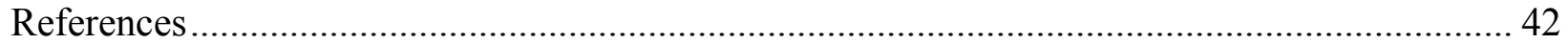

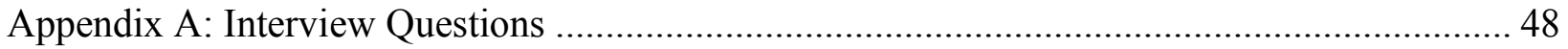

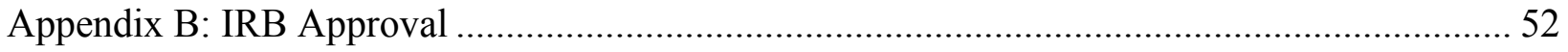




\section{Chapter 1 Introduction}

I am first-generation Mexican American, who was afforded somewhat of a privileged upbringing, in that my parents sent me to the best public school in the neighborhood. I was able to play sports, maintained good grades, but I did not have the means to pay for college out of pocket. Towards the end of my college years my parents separated. While this isn't uncommon for families, what I did not know was how much it would impact me. I went from having a supportive father, to a father who kicked my family out of my childhood home. This all happened while I was in my teaching credential program. Only my advisor and a few in my cohort knew what I was experiencing. I had had no idea that this change in my home life would disrupt my academic life, as well. While in the credential program, I was working 40 plus hours a week to make ends meet. I was frantically looking for a place to live. I was living paycheck to paycheck. I was helping my mom financially support my younger siblings as much as I could, as well as helping her fight a custody battle. As a result, I took the CSET in sections because I never had extra money lying around to afford the full amount. I was stressed out and did not know if I would even be able to complete the program. It got to the point where I had failed the last CSET that I needed in order to begin my semester student teaching. I had received a new advisor through that year, and I explained my situation to her. I pleaded with her for a way to start student teaching before finishing my exams. I asked for an alternative; after all is that not what was taught to us during our credential program, to accommodate our students? I explained my life situation and her reply was, "you just have to think positive." The anger and frustration of hearing those words made me cry all the way home, but it also motivated me to think about how many other first-generation students and students of color were out there with situations 
similar to mine that were being ignored or told to "think positive" in situations that they had no control over.

How many experiences were being invalidated by the biased opinion that if everyone else can do it, so can you? Now, the advisor's advice was not maliciously given. In fact, I wholeheartedly believe that she thought that she was helping me. But for the reality of students like me, thinking positive is not something that will help us out of monetary situations. It made me reflect on my experience in my credential program. I was one of the few students of color within this program. Why were there no other student teachers that looked like me? In fact, why were there so few Teachers of Color that looked like me? Was a career in education unattainable for People of Color? If so, what needs to change to ensure that we have a diverse teacher workforce that matches the diversity of our student population?

\section{Statement of Purpose}

Previous studies have attempted to address this problem. Much of the fundamental literature of this study used Critical Race Theory (CRT) to tackle systemic racism in education. CRT stems from People of Color and their allies being tired with how slow social change was occurring (Ladson-Billings, 2019). It is used to critically analyze systems that need to be reformed at a faster pace. However, even with the incorporation of CRT there were still some gaps in their data. Most of the literature centered around numerical data and lacked the voices of Teachers of Color. Additionally, when voices of TOC were incorporated it typically stuck with either gender or race. Furthermore, when literature talked about Whiteness, White Supremacy or White Fragility, TOCs were never asked about their own personal experience. As the data of my research will show, it is important to understand how ignoring intersectionality and White Supremacy can impact People of Color in education. 


\section{Overview of Research Design}

A qualitative methods approach was used for this study. An emphasis on constructivist worldview was incorporated to examine and analyze the many lived experiences of the participants. Five Teachers of Color were interviewed about their experience in pursuing a career in education.

This study was conducted at a school district in Vallejo, California. The student demographic is primarily African American. The participants of this study worked at the same school I did as well as the two other sites in the district. All but one of the participants were teachers who identified as African American/Black with the last participant identified Latinx. Data was collected through in person or over the phone interviews. As a fellow Teacher of Color, it allowed me to conduct the interviews in a more comfortable relaxed setting as there was a level of familiarity in our similar experiences as TOCs.

Interviews were held to gather data, they were recorded and transcribed. Open coding was used to categorize the themes and experiences of Teachers of Color, followed by organizing the themes in matrix to see commonalities. Follow-up conversations with a few of the research participants did occur to address clarification on the interpretation of the data.

\section{Significance of Findings}

Throughout this research and my personal experiences, I have learned that it is difficult to have conversations about difficult topics before there are terms and vocabulary to even name the experience. The findings of this research was a process of naming these experiences that TOC and POC have on a daily basis. The naming of these experiences will allow for future research to clearly pinpoint what changes need to happen. When we ignore intersectionality and White Supremacy in institutions, whether it is the field of education or others, we give Whiteness the 
power to maintain itself. By naming and addressing the experiences of POC, it gives back some of the power that White Supremacy has taken from marginalized groups. It gives those who are marginalized the ability to call it out and bring attention to the injustices that we silently endured for a long time. In order to fully address the inequity in the field of education, these voices of the marginalized need to be uplifted and heard. It is not enough to just incorporate bits and pieces of social justice in our schools, but we truly need to transform the way we teach, learn, and educate our students in understanding the meaning behind being Dismissed, Silenced, Censored, and becoming Exhausted in a Colorblind Workplace.

\section{Implications}

In order to address the issue of a lack of Teachers of Color, we need to reinvigorate the way we train, teach, and recruit our teachers. First, we need to look into Teacher Preparation Programs to see what changes need to occur to make them more equitable. Second, we need to have more conversations about the experiences of Teachers of color. Lastly, we need teacher development based on cultural responsiveness needs to be implemented across school. The findings of my research provide a useful tool in bridging that understanding between the stakeholders, including administration, school districts, and Teachers of Color to ensure that TOCs are being represented and heard 


\section{Chapter 2 Literature Review}

Patton (2015) has shown that education has been historically guaranteed to the white, rich and privileged. That ideology of White Privilege and opportunity is still prevalent in education today, but has morphed and been hidden under policies and systems such as systemically racist testing, expensive CSETS, requiring unpaid internships, etc. Whether intentional or not, most of these systemic barriers inherently deter People of Color from pursuing higher education. (Rogers-Ard et al., 2012). This exclusion at first was deliberate and whether it continues to be intentional or not, the structural inequities of the system were built in such a way that they uphold the barriers and injustices of White Supremacy (Patton 2015).

Hayes \& Fashing-Varner (2015) have shown that there is a lack of Teachers of Color in the United States and this stems from Whiteness blocking People of Color (POC) from potentially pursuing a career in education. Teacher preparation programs have attempted to address the issues of equity and diversity with the public student population but have yet to address these issues in their programs (Matias et al., 2016). The voices of Teachers of Color are being ignored and erased, because White Fragility blocks attempts to remedy the problem. DiAngelo (2011) defines White Fragility as "a state in which even a minimum amount of racial stress becomes intolerable, triggering a range of defensive moves" (p. 54). These defensive moves from white people block conversations that need to happen in order to address the invisible racism that is embedded into the education system. People of color continuously navigate the thin line of White Fragility when addressing inequities (DiAngelo, 2019). Matias, et al. (2016) makes the point that we need to change the way teachers are being trained to help recruit and retain Teachers of Color (TOC). 
POC have long struggled to achieve equality in the United States. It is well known that in order to achieve equality or climb the social ladder, education is one of the key tools. However, education in the United States is systemically racist (Patton 2015). The population of publicschool students as of fall 2019, more than half the students are students of color. (National Center for Education Statistics). Yet, the demographics for the teachers is about $80 \%$ white. (National Center for Education Statistics). This lack of Teachers of Color promotes systemic racism in the United States. Instead of addressing the issue of the lack of TOC, Teacher Preparation Programs (TPP) focus on teaching white teachers how to teach students of color without much input from actual Teachers of Color (Rogers-Ard et al., 2012). Teachers of Color bring many benefits to these conversations and their roles as educators (Jackson \& Kohli 2016). One of the many benefits of TOC is that they are role models for students of color. Students of color rarely see POC in leader roles, and just by seeing POC in educator roles it promotes the idea that they too can become anything (Williams, 2018). In addition, TOCs bring culturally responsive pedagogy that makes cultural connections to all their students (Carr \& Klassen, 1997). Educating and training students who will become future adults. Furthermore, TOCs bring their own personal experience as a POC to connect with their students (Andrews et al, 2018).

\section{Historical Background}

Beyoncé Knowles once said while honoring Colin Kaepernick for Sports Illustrated SportsPerson of the Year Award (2017) that, "racism is so American, that when we protest racism, some assume we are protesting America." To fully understand how deeply embedded racism is in our education we must look to the beginning of the creation of the United States of America. The United States was founded on the idea that all men are created equal. This, however, did not include women and People of Color until much later with the addition of the 
13th Amendment (1865) which prohibited slavery, the 15th amendment (1869) which granted Black men the right to vote and 19th amendment (1919) which granted women the right to vote. Even then, it wasn't until the Civil Rights Act of 1964 that African American and other POC fully got their rights to vote. Additionally, the constitution does not address the topic of education. There is no amendment that protects the right to education. The founding fathers allowed for states to have the discretion of what they wanted to do in regard to education. This has allowed for many systemic issues to occur and even more so to People of Color. One example was in the San Antonio Independent School District v. Rodriguez Supreme Court case of 1972. The district sued the state because students were being underserved in that area. The area where the school was located was predominantly low income and because funding for schools was based off property taxes, the school was not receiving enough funds. The district attempted to use the Equal Protection clause of the 14th amendment to gain equal funding. The court, however, stated that the constitution does not guarantee equal access to education. While this is a more recent example of the systemic issues of education, this has been occurring silently throughout our history.

\section{Systemic Racism in Education, HBCUs and the Exclusion of TOC's}

Patton (2015) makes the point that we must remember that this country was built off the backs of slavery and off the stolen land of Native Americans, to deny this is to say that it did not happen at all. Many would argue that those were the choices of our past ancestors however, it does not negate the fact that many continue to reap the benefits of those ancestors (Patton, 2015). The instant access that many White, slave-owning plantation holders had to education, provided generational wealth that many African Americans were denied. This can be seen through many 
of the systems that were in place to continue to oppress Black and African American people continuously throughout the U.S history.

Irvine \& Fenwick (2011) note that after slavery ended, there was nothing in place to help support all the newly freed slaves, and that many had to return to work at the plantations that had owned them because they did not have the education needed for other jobs. This tragic cycle of being given freedom only to return freely to the place that held them as slaves led to the creation and rise in Historically Black Colleges and Universities (HBCUs), which were created to help newly freed slaves gain the education that they were not provided. They were pivotal in the education of African Americans generally, and, in the era before even "separate but equal", training of African Americans as teachers for African American children (Rogers-Ard et al., 2012).

Throughout U.S history, African Americans and other POC have continuously fought to achieve equality. The Civil Rights Era changed how White people saw racism (DiAngelo, 2019). Alexander (2010) corroborates D'Angelo's statements of a social change on how people view racism. She states that there is a new caste system after Jim Crow. "The new system had been developed and implemented swiftly and it was largely invisible, even to people, like me, who spent most of their waking hours fighting for justice" (p.3). A new form of racism grew from the ashes of the blatant Jim Crow era of racism. Veloria (2015) describes how this racism is subtle and disguised under "well-meaning" intentions protected by other white people who claimed to be blind to race. "A new race neutral language was developed for appealing to old racist sentiments, a language accompanied by a political movement that succeeded in putting the majority of Blacks back in their place" (Alexander, 2010 p.40). This new racism and language is what supports the many systems in place that are used to oppress POC. 
Andrews et al. (2018) makes the argument that one of the more prevalent examples of this new racism is Brown vs. Board of Education; it is seen as one of the many great achievements of the Civil Right Era in stating that "separate is not equal" and that all public schools should be integrated, but it also de facto created a different type of segregation; the segregation of Black Teachers. HBCUs, as noted, had long been producing Black teachers to teach the Black students that White teachers did not want to teach (Rogers-Ard et al., 2012). Rogers-Ard et al. (2012) also noted when desegregation was required it was Black teachers who lost their jobs because the U.S moved to educate everyone from a white perspective.

\section{Parallel Educational Barriers for Native Americans and Latinx}

Similarly, Native Americans and Latinx have a long battle history for education in the U.S. This country was built off the stolen land of Indigenous tribes, and the abuse that Indigenous Peoples (Native Americans) have suffered through our own education system is another way that systemic barriers continue to occur (Huerta, 2009). Originally, Indigenous people would be thrown into schools to be assimilated in the "American" way of life. They were robbed of their traditions, culture, language, and identity, as well as tortured, beaten and murdered until they conformed to what White people saw as civilized (Lowen, 1995) With the momentum of the Civil Rights movement, Indigenous tribes were able to advocate for themselves and create their own education programs. However, there is a lack of funding at Native American schools that led to "high suspension and expulsion rates, and the highest percentage of all groups to report injury with weapons and fights on school grounds." (American Indians/Alaska Natives: Education Issues). Furthermore, this lack of funding is not accidental but intentional (Boone \& Bellwether Education Partners, 2018). Once Indigenous tribes obtained 
their sovereignty, the U.S Federal government did not put as much emphasis on the aid they once promised. Claren (2007) provides the example of The Johnson O'Malley program:

The Johnson O'Malley program, created in 1934 to fund basic educational needs of Native students, disperses money based on the number of enrolled tribal members attending public school. Congress hasn't completed the necessary population survey since 1994, while the number of Native students has grown by approximately 4 percent per year-meaning that the same pool of money authorized in 1994 must now cover far more children.

During a speech at Moscow State University, President Reagan said that Indigenous peoples' problems were nobody's fault but their own (Bastard Fairy Films, 2006). This dismissiveness and victim blaming is a consistent pattern with regards to assisting POC within the field of Education (Carr, 2006).

Furthermore, Huerta (2009) maintains that Latinx people have also struggled with getting a decent education. Mexican Americans have been pushed and pulled, wanted and unwanted even before the Mexican American War. As a result of colonization, Mexican heritage has been mixed with many European countries. Ortiz \& Telles (2012) state that this adds a complicated dimension as to how to classify Mexican-Americans:

Mexicans are heterogeneous in their racial characteristics, ranging from having light to dark skin and eye color with many in the brown and mestizo middle. Outsiders tend not to see Mexicans as White or Black. Rather they are viewed through the stereotypic lens of being nonwhite or brown and largely indigenous-looking.

As a result, Latinx people were treated as second class, just as Indigenous people, once the U.S took over what had once been Mexican territory. Huerta (2009) documents how Mexican 
students were also segregated into their low funded schools that did not have the resources necessary to help students be successful. Brown vs. The Board of Education included the desegregation of Mexican and other Latinx students (Pribanic-Smith, 2015). But just like all other POC, this did not change the many years of underfunded education (Menchaca \& Valencia, 1990)

In order to understand why there is a lack of Teachers of Colors, Williams (2018) argues that we need to understand the history of POC in our education system, and how it was built with forms of systemic inequities and blatant racism. We need to change many of the systemic issues that were only tweaked to semi-incorporate POC and claim inclusion. Once we see that our education system is systemically racist, we can do the work necessary to ensure equitable education.

\section{Systemic Barriers}

Education needs to evolve and change. Diversity should not only be a marker to check off. We cannot diversify the educational workforce if they do not address the systemic barriers that are in place: economic, social, racial, and political. Historically, we have seen these categories as separate entities. Kimberlé Crenshaw (2017) coined the term Intersectionality. She defines it as: "Intersectionality is a lens through which you can see where power comes and collides, where it interlocks and intersects. It's not simply that there's a race problem here, a gender problem here, and a class or LBGTQ problem there" (Para 3). While the categories are organized as separate below, all categories intersect in a way that can benefit or hinder POC. These barriers do not stand alone, and it is pivotal to understand how they interconnect. 


\section{Economic}

Rogers et al. (2012) cite a lack of financial resources and funding as a barrier that can impact anyone regardless of race, but when combined with race it makes it difficult to overcome. These researchers conducted a study looking at two urban programs that helped train, recruit and retain Teachers of Color; Oakland Partnership Program and Teach Tomorrow Oakland. Oakland had a hard time fully desegregating, and it can still be seen through their district lines, charter and private schools (Kirp 1979). Oakland lacked teachers but more importantly lacked culturally responsive teachers. Rogers et al. (2012) noticed that a huge number of Teachers of Color did not finish credential programs or went into careers that did not require additional certification. Andrews et al. (2018) identified the amount of unpaid work student teachers are required to do, as well as the tests that they are required to pay for as important deterrents. Rogers et al. (2012) made that case that systemically POC cannot afford to do a full year of unpaid student teaching and still keep themselves financially afloat.

\section{Social \& Racial}

DiAngelo (2019) argues that there is a common misconception in the U.S about racism, and that many people want to believe we live in a post racial world, often citing the election of a Black president as proof. DiAngelo maintains that racism is still alive, and it has evolved, despite suggestions that people have to the contrary. The racism before the Civil Rights movement is not the same racism that POC experience in their everyday lives in the 21 st Century. Veloria (2015) illuminates this "new racism" which she defines as an "invisible system of dominion and power" (p.37). Examples of this "new racism" include people being less likely to be hired because they have Black sounding name versus old racism which would be more overt, such as refusing service to People of Color or the use of racist and demeaning language (DiAngelo, 2019). In 
education this "new racism" can be seen through policies such as the 2002 No Child Left Behind (NCLB). The NCLB is laced with colorblindness making it a participant of "new racism". DiAngelo (2012) states that colorblindness is an ideology where people claim that they do not see race. Leonardo (2007) argues that "Its white common sense deems racial disparities as unfortunate outcomes of group competition, uneven social development, or worse, as stubborn cultural explanations of the inferiority of people of color" (p. 261). Furthermore, we can see this "new racism" in the social phenomena that is white flight. White flight began after Brown vs Board of Education desegregated public schools and demanded the integration of Black and white students (Renzulli \& Evans, 2005). Many white parents did not like this and thus decided to "flee" into suburban areas mainly populated by white people. Eventually creating their own private or charter schools meant only for their children (Jayapaal, 1987). We can still see the ramifications of white flight in cities like Baltimore, Maryland by looking at their school trends. Their school trends between public and private show how prevalent "new racism" is still in place. Statistical Atlas statistics on Baltimore's Public and Private schools in 2016 demonstrates how unequitable their education system has become even after being one of the first cities to desegregate. There are 225 private schools in Baltimore County, MD, serving 43,542 students, additionally there are 166 public schools in Baltimore County, MD, serving 104,829 students. In private schools, minority enrollment is $31 \%$ of the student body. On the other hand, in public schools, $97.9 \%$ of the student body is minority enrollment. While many may not see these examples as racism and may even state those policies or private schools are meant to benefit everyone. It is POC who suffer the effects of this invisible racism.

This "new racism" is deeply embedded into the field of education, and TOCs feel it deeply, and in multiple ways. Andrews et al. (2018) identify how TOC's are often placed in 
disciplinary roles, hired as the token minority and based on their race and not their qualifications. Hayes \& Fashing-Varner (2015) documents how when POC are eventually hired, they often face hostile environments, especially when they try to bring in culturally responsive pedagogy. They address this "new racism" through the experience of Marcus. His story revolves around a group of white students complaining that they felt they were not learning the necessary strategies to help students pass standardized tests. The department chair addressed the complaints with him, and he simply stated that if teachers are not being taught culturally relevant pedagogy, no strategies would help them get students to pass the tests, especially the most vulnerable students. The chair saw it as Marcus teaching "how to be sensitive to Black kids" (p. 106), and Marcus was reprimanded for his attempt to incorporate culturally responsive teaching. In addition to ignoring culturally responsive teaching when it comes from POC, many schools place TOC, specifically Black Male teachers in disciplinary roles. Conwright (2019) describes it as "white

muscle" in a Black body. He states "the "remedy" of empowered whites using the social clout of African Americans to convince Blacks to acquiesce to discipline follows an enduring legacy of education's marriage to racist practices."

\section{Political: White Supremacy}

As a political barrier we have policies and procedures in place that are systemically racist and which reinforce forms of White Supremacy (DiAngelo, 2019. Patton (2015) argues that policies that were in place before desegregation, forces of that political climate, were often explicitly racist and meant to keep POC oppressed; and after desegregation the same forces maintained racist forms of oppression in subtle ways. White Supremacy is placed as a political barrier because it is deeply embedded in our own government (DiAngelo, 2019): "Race is the child of racism, not the father," meaning we exploited people for their resources and then created 
the idea of races to justify it. Additionally, Alexander (2010) supports this idea. She states that "The notion of white supremacy rationalized the enslavement of Africans, even as whites endeavor to form a new nation based on the ideals of equality, liberty, and justice for all” (p.25). This can be seen through the 13th Amendment. The 13th Amendment prohibited slavery except in terms of punishment for a crime. This loophole would be exploited and lead to the mass incarceration of Black/African Americans (Alexander, 2005).

\section{Theoretical Frameworks}

The study described in the paper is guided by theories and concepts that will assist me in understanding the systemic issues underlying Teacher Preparation Programs/Higher Education with regards to the experiences of POC. Our experiences, whether, male or female, white or POC shape our lived experiences. The many intersections of our identities help shape who we are and provide insight into what systemic barriers may seem invisible to some. This section provides an overview of Critical Race Theory (CRT) and the tenants being used. In addition to CRT, the Critical study of Whiteness will be a guiding point in informing how to approach dismantling White Supremacy in Education. Lastly, an overview of Microaggressions to provide insight into the experiences of TOC in education.

\section{Critical Race Theory}

Critical Race Theory (CRT) came from Critical Legal Studies (CLS). It stemmed from legal scholars of color concern that racial reform was not happening at a fast-enough pace and the idea of meritocracy in the U.S and the failure to include racism in its critique (LadsonBillings, 2019). Ladson-Billings (2019) used CRT to analyze what needed to change in order for racial reform to happen at a faster pace. Below are the CRT tenants that will be used in this study. 
CRT tenant 1: critique of liberalism. This tenant addresses the discontent with liberalism. Essentially, the discontent in how it is used to address the racial problems (Delgado \& Stefanic, 1993). CRT scholars argue that while liberalism has good intentions, their use of colorblindness and meritocracy delay the racial changes that need to be made. CRT is used to criticize liberalism and the slow progression of racial equality, especially since whites have been the prime beneficiaries of any civil rights legislation (Ladson-Billings, 2019).

CRT tenant 2: storytelling/counter-storytelling. Storytelling is used in CRT as a way to provide a voice to those who are often ignored. Storytelling and Counter-Storytelling is often used as a way to expose racism and experience it through the realities of those who often deal with racism the most (Dickenson, 2012). The voices of the marginalized are often erased or ignored CRT ensures that this does not occur.

CRT tenant 3: intersectionality \& essentialism. Intersectionality importantly addresses the multiple interconnectedness of our identities (Bryant Moss \& Boudreau, 2015). For example, the lived experience of a gay Latina women is vastly different than that of a Black woman. Essentialism means that while they both share the identity of being women and will experience sexism. They will experience other parts of their identity differently (Bryant, Moss \& Boudreau, 2015). With regards to racism, the Latina woman has light-skinned privilege, and will not be profiled as harshly by the color of her skin. On the other hand, the Latina women will experience homophobia that the Black women will not (Cardabo, 2013). This is important because some parts of our identities help promote us, and others hinder us.

Following CRT, the Critical study of Whiteness is important. DiAngelo (2019) describes a defensive phenomenon that occurs when the conversation of race and ethnicity is brought up among whites. Therefore, using Critical study of Whiteness is important to address. 


\section{Critical study of Whiteness}

CRT addresses the Concept of Whiteness, but it is so multifaceted that it needs to be under its own lens. It is an identity, a policy and a source of power that is continuously used to oppress POC (Green, Sonn \& Matsebula, 2007). Green, Sonn \& Matsebula (2007) additionally state that there are three main characteristics to the Critical study of Whiteness:

Characteristic 1. The first characteristic states that Whiteness is powerful and when White people ignore, resist, or deny it, it only adds to the power that it already holds (Haviland 2008). DiAngelo (2019) also states, "only whites have the collective social and social institutional power and privilege over People of Color. People of color do not have this power and privilege over white people" (p.75)

Characteristic 2. Haviland (2008) additionally states that ignore, resist, or denying Whiteness, it only adds to the power that it already holds. The second characteristic, Whiteness employs numerous techniques to maintain its power. One example is the concept of meritocracy. The idea that if someone works hard enough, they can achieve their goals. This system of meritocracy ignores the invisible barriers that many People of Color face (Williams 2018).

Characteristic 3. This characteristic state that Whiteness is not monolithic, this means the White people can learn to change (Haviland 2008). However, DiAngelo (2019) states that they must be willing to change. If white people are not open to being called out and learning, systems will be hard to change.

\section{Microaggressions}

Microaggressions can be interpreted differently by different social and racial groups (DiAngelo 2019). Huber \& Solorzano (2014) identified 3 different forms of Microaggressions that POC experience: 
1. Verbal and Non-Verbal: They are carried out in a subtle unconscious way such as a person clutching their purse closer to themselves when a man of color enters an elevator.

2. Layered assaults: These are based on race and its intersections. Cardabo (2013) explains this through multiple cases. One example is the old military policy of Don't Ask, Don't Tell policy. When this policy was being dismantled it was White Gay men who were the poster child for the movement, Black Gay Men on the other had did not qualify for this. Cardabodo (2013) states that while being a man has its privileges, being a Black man and its intersections tends to be more difficult: "If being gay like white heterosexual man is platable to the main stream American public, being a Black presumptively heterosexual man generally is not" ( $p$. 836).

3. Cumulative assaults: These are assaults that take a physiological, psychological, and academic toll on People of Color (Solorzano, Ceja, \& Yosso, 2000).

In general, Microaggressions are much harder to identify than blatant racism, most POC internalize Microaggressions which is why there is not much research on how Microaggressions affect TOC in the field of education.

\section{Benefits of Teachers of Color}

Adding People of Colors to the education field should not just be a checkmark for diversity. Research has shown it also provides multiple benefits to the students who engage with Teachers of Color (Andrews et al., 2018, Irvine \& Finick 2008).

To begin TOC, have many of the same lived experiences as their student of colors (Jackson \& Kohli 2016, Gomez 2014). DiAngelo (2019) states that POC have a hard time talking about their experiences with White people because they do not understand the struggle POC often face or deny that they experience them. This is not to say that White teachers cannot have 
meaningful relationships with their students of color, it just may make it difficult to do so if the teacher is white. TOC of color understand their home life, their culture and customs either because they share the same culture or know the experience of feeling outcasted because of their culture and they want students to be comfortable.

In addition, TOCs bring culturally relevant pedagogy to the classroom (Andrews et al., 2018). Whether they are a classroom teacher or a professor at a college, TOCs bring culturally relevant pedagogy into their classrooms (Irvine \& Fenwick 2011). Carr \& Klassen (1997) found that overwhelmingly many White teachers had many of the same belief systems in regard to race such as: Race does not play a role in teacher - student relationship, equity-based employment would lead to reverse discrimination, and that racial minorities do not face discrimination. On the other hand, TOC agree that an anti-racist education is important in schools, race/culture do play a role in teacher-student relationships, support for equity employments and that POC do face discrimination that their White peers do not (Carr \& Klassen 1997, Gomez 2014, Irvine \& Fenwick 2011).

Furthermore, TOCs serve as role models to their Students of Color. Baker (1983) states

"The attitude of the teacher is crucial in helping students develop attitudes that will prepare them for a harmonious existence in a society that is culturally diverse" (p.43). Additionally, Williams (2018) states that Black teachers help students know how to counter issues of degradation. TOCs not only act as role models, they also push their students to achieve higher goals. (Irvine \& Fenwick 2011).

\section{Conclusion}

There is much research on the role of Critical Race Theory in the field of education. The literature points to changing the way education is being conveyed, especially when it comes to 
the training of teachers. Vast amount of ways that CRT can be used to create an authentic study by incorporating the perspectives of POC. However, there is a Lack of CRT strategies actually being implemented and especially a lack of perspectives of POC. Most studies state that there needs to be a change, yet do not offer any many solutions. As stated before, there is much research on using CRT as a framework, but there is not much research actually incorporating what TOC have to say they would like to see change in the field of education. The purpose of this research is to better understand how to combat systemic racism in the field of education from the perspective of Teachers of Color. From the perspective of TOC, what do we need to do in order to retain and recruit Teachers of Color to provide a more equitable education to future students? 


\section{Chapter 3 Methods}

This study analyzed the experiences and perspectives of Teachers of Colors within, during and after gaining a teaching credential. In particular this study used CRT, Critical Whiteness Theory and theories on Microaggressions to analyze the experiences of Teachers of Color. This study sought to answer the following central question: How does ignoring intersectionality and White Supremacy impact People of Color in education?

\section{Research Questions}

The overarching question: How does ignoring intersectionality and White Supremacy impact People of Color in education. Previous studies have shown how ignoring White Supremacy awards it more power in everyday circumstances (DiAngelo, 2019). By using this research question, I explored the experiences of Teachers of Color navigating through White Supremacy in education by using an intersectional lens. The research question helps break down the interview questions into categories of their experiences. To start we have interview questions that ask about their experiences throughout their teaching credential program, followed by their experiences as students of color in educational institutions such as 4-year college, credential program, or master's program, then their experiences as Teachers of Color and finally questions about their experiences dealing with Whiteness and White Supremacy (See Appendix A). The interview questions are broken down into these categories to demonstrate what People of Color experience through every stage of attempting to become a teacher. The last section about Whiteness and White Supremacy is necessary in order to name these experiences as well as to bring forth any experiences that participants may directly connect to those topics. 


\section{Research Approach}

This study used a qualitative methods approach with an emphasis on a constructivist worldview. A social constructionist world view "believes that individuals seek understanding of the world in which they live and work" (Creswell, 2018, p. 7). By using this approach, the researcher's role was to examine and interpret the meanings of the lived experiences of others. Previous research has found that Teachers of Color bring many benefits to the classroom. In order to gain a better understanding of what Teachers of Color experience, the research interviewed current teachers to gain insight into their experiences and perspectives.

A qualitative approach was chosen for this study in order to fully understand the experiences and perspectives of Teachers of Color. With this approach, the researcher conducted in person interviews, analyzed the data, had follow up conversations and re-analyzed the data and using open-ended questions (Creswell, 2018). A qualitative approach was used for this research to incorporate the counter stories exemplified in CRT (Ladson-Billings, 2019). Knowing the perspectives of TOC, can help educate Teacher Preparation Programs to help them see the systemic racism that Whiteness continues to uphold. Participants in the study were Teachers of Color working in middle schools and high schoo. Their background experiences and perspectives in a credential program and as classroom teachers provided insightful knowledge that helped understand why there is a lack of Teachers of Color. The interviews were conducted using open ended questions to ensure a more natural, comfortable conversation.

\section{Research Design}

Research sites. The research was conducted at Griffin Technology Academies, which includes two urban middle schools and a high school serving sixth through twelfth graders in Northern California. There are over 800 students attending, with an extremely diverse 
population. 70\% Hispanic, 19\% African American, 18\% Filipino, 12\% White, 3\% Asian, 1.4\% other .4\% Pacific Islander, .2\% Indian and .08\% two or more.

Participants. The participants involved in this study were a variety of ages, races and ethnicity. All participants of the study were teachers who had at least a year of teaching, in a credential program and were classroom teachers. Participants were recruited purposefully for the research to ensure that the central question was addressed.

Sampling Procedure. The research purposefully asked Teachers of Color if they were willing to participate in study and then scheduled an interview. The researcher also used snowball sampling and asked participants if they had any other teachers that they would recommend for the study.

\section{Methods}

Interview questions were used for data collection. Interviews were recorded through a password protected phone and transcribed using an online software program called Otter. After transcription data was recorded by hand and organized by questions. Each question had all 5 interview answers below it color coded by interview. This form of coding helped identify the similarities and differences between the experiences of Teachers of Color. For example, in the category Questions about Teacher of Color experience, there are two questions that are similar but highlight different experiences. The first "How do you feel as a teacher around white teachers?" focuses on the experience of Teachers of Color around white teachers and the second question "How do you feel as a teacher around teachers of color?" focuses on the experiences around Teachers of Color. If this question was framed as one such as "How do you feel as a teacher of color around white teachers and Teachers of Color", the distinction in experiences 
may not be clear if asked in this format as the distinction between the two experiences with the types of teachers would be muddled. (See Appendix A)

\section{Data analysis.}

The research consists of only Qualitative data. Qualitative data analysis method was used to analyze the interviews. All interviews were recorded and transcribed by the author. The researcher listened to the interviews and wrote down memos before transcribing to capture any statements missed during the initial interview.

The transcribed interviews were read along with the audio while the researcher wrote down similarities and differences that are then categorized into codes. These codes were then categorized into themes prevalent in the literature review including but not limited to Microaggressions, Whiteness, Barriers, Racism etc. Open coding allowed for the researcher to create new categories that prior research may have not addressed. Data was then organized in a matrix to potentially see missing connections. The codes were then renamed once common themes and connections arose, to represent the lived experiences of the research participants. (See Chapter 4)

The process of data collection went as follows: qualitative data was collected through interviews notes, transcription of audio-taped interviews and coding of the interviews. First, interviews were conducted. The researcher took notes and recorded the interview as it occurred. Second, the researcher listened to the interview and wrote down memos of themes that may have been missed the first time. Then, the transcription of the interviews occurred. Next, coding of the transcribed interviews occurred to see if any themes were recurring among the interviews. Additionally, the researcher had conversations at a later time with participants after the interviews for clarification or to expand on ideas and themes already stated. 


\section{Validity and reliability}

In order to ensure validity, the researcher triangulated the data, peer debriefing and member check. Two types of triangulation will be used in this study; Data Triangulation and Theory Triangulation. Data Triangulation will occur through the multiple interviews and analysis of data, while Theory Triangulation will be used while analyzing the data through the theoretical framework (Creswell, 2018, Maxwell, 2013).

Member checking will consist of conducting follow-up conversations (Maxwell, 2018). Participants had access to these transcripts to confirm accuracy and expand on any part of the interview.

In regard to peer debriefing, the researcher asked individuals who were not involved with the study to help the researcher detect any problems that may have occurred such as: overemphasized points, underemphasized points, vague descriptions, general errors in the data, biases or assumptions made by the researcher. At least one peer debriefed will be incorporated into the validity of this study.

\section{Positionality}

As a researcher, I have experienced all roles categorized in the study. As a person of color, student teacher of color, and a teacher of color, I have experienced the education system from the perspective of the participants of the study. As a student-teacher of color, I found the process of becoming a teacher challenging in many of the ways that POC face challenges. Some of the challenges that stemmed from being a person of color were the lack of financial support that my family could provide, having to pay for my own education, being first generation, lack of access to viable networks and many more. Throughout the journey of my teacher preparation program, I realized that many in my cohort did not face the same struggles as I did as well as the 
fact that I was one of the few Teachers of Color. As a teacher of color, I have already had to face many Microaggressions with teachers who have a colorblind ideology, creating hostility and resentment from colleagues. I am fully aware that my positionality will affect my bias, however, my purpose is not to fabricate experiences rather to use storytelling/counter stories to have institutions such as schools and teacher preparation programs understand the experiences of Teachers of Color in these systems. This positionality also added validity to the findings because People of Color are more comfortable talking to other People of Color when it comes to the topic of Racism and White Supremacy. I am seen as one of them, part of the effort to create change. My positionality allows for there to be trust between the researcher and the participant. Since I work at the school where the interviews will be conducted and have had a working relationship with most of the participants, this will lead to more valid and accurate findings. Most participants have been teachers for longer than 2 years compared to my 1-year experience, this will also help as participants will feel like they are offering advice. In addition, I share my experiences beforehand to foster a trustworthy relationship. 


\section{Chapter 4 Data Analysis}

The data of this research is the lived experiences of the participants. Therefore, the data analysis reads as a story, a lesson to be learned. As a fellow teacher of color, I include myself in solidarity to the experiences of my fellow participants. Many of their own experiences reflect my own. The topics of White Privilege, White Supremacy, and White Fragility show up as the tip of the iceberg. Without the participants' experiences with these terms we would not have the underlying terms that would be the bottom of the iceberg. The 3 W's, as I refer to them below, create a Colorblind Work place where TOCs become exhausted with having to be a token minority. Many of the themes noted below are not new experiences but have finally been named.

When I began talking to Dana, an interview participant, about her experiences with White Privilege her description of decorating her classroom struck me. As a teacher, many of us do not think about our race and ethnicity when decorating our classroom. We decorate our classroom to make it feel welcoming to ourselves and our students. Dana's experience gave me the opportunity to check my own privileges:

So, it's like the stuff you don't even think about posters, images, what classroom, even the feeling of like when you walk into a classroom, what makes you feel welcome. In the classroom that I have now, it is not to make me feel welcome, it is to say this is the classroom environment. What makes me feel welcome is those dark earthy colors like, if you were to come into my classroom like that somebody would have a problem with it because it would be like "oh no, that's too Black, that's too African

Dana's experience is that of many POC. Where we feel that we may become "too this" or "too that" and judged by preconceived notions of whatever label is placed on us. While this may 
be a subtle way of how White Privilege is in education, it can come in a much more blatant form.

Whiteness permeates all aspects of education. All participants agreed that the $3 \mathrm{~W}$ 's (White Fragility, White Supremacy and White Privilege) are interconnected. Joseph stated that it's a cycle and it starts with White Fragility. "Almost like an inferiority complex that people tend to have, you know, and they project that onto you with White Supremacy like I'm better than you I'ma prove it" He adds that White Fragility then leads to White Supremacy, the idea that because they are white, they are then better than everyone who is not. This, in turn, leads to White Privilege because they are then given opportunities offered to them because of White Supremacy. But, if they lose the White Privilege that they once had, their White Fragility comes back and reinstates the cycle. We can see the effects of Whiteness in every experience stated above. They reinforce stereotypes, biases and preconceived notions on people. Whiteness is the force that silences TOC and if we want to reduce the achievement gap and have all our students become successful then we need to adamantly address that it is in our education system.

All interview participants were asked what they thought needed to be done to address the 3 W's in education. Most said that the process of becoming an educator in California is too expensive, and that there are unrealistic expectations of people attempting to earn a credential such as a year on unpaid student teaching and expensive tests. Not only are there unrealistic expectations, but many of those who cannot afford to do a year of unpaid teaching miss valuable opportunities because they have to work multiple jobs to make ends meet. Those that are most affected by these issues tend to be POC. These issues make a career in education unattainable and not worth the work, especially when we look at how much teachers are paid. To fight 
Whiteness, we need to make the process of gaining a credential more equitable, to ensure that more POC pursue a career in education.

Tackling the $3 \mathrm{~W}$ 's on a social level is another challenge that TOCs face. Another teacher, a proud Black African American woman, Carmen, was heavily involved in the Union at the school site and dealt with a lot of White Fragility. She gave me this example about how people perceive her:

If I'm speaking to you like we're speaking, have a conversation right now, let's say that the conversation changes and I need to say: "Ms. Vallejo, I do not like how you spoke to that student yesterday." Let's just say I said something like that, and I was just being in a serious tone. They will take it as an offense even if I'm calm, like I'm just talking like this. Oh, no, I'm turning up. I'm aggressive. I'm doing too much. How? She is passionate about this and she wanted to speak to you about something too. Why is it that I am aggressive? When I'm not yelling? I'm not cursing? So, I don't like the fact that I'm read wrong all the time. It just makes me want to stay in my little bubble.

In her experience she was judged by her race. She was not offered the opportunity to be herself or address a situation without having to think about how people would perceive her. She intentionally had to censor herself. This Intentional Censoring is one of the barriers that Teachers of Color face. Not only do we have to fight to be heard, we have to ensure what we are saying is not misinterpreted in a negative way. Intentional Censoring happens when POC, know that they will be perceived a certain way and decide to withhold information, change the way they would authentically address situations or even not address a situation at all. However, this Intentional Censoring is done out of Exhaustion of dealing with White Fragility. Amy, a 6th grade EL teacher, goes on to say: "I don't know how many times I can argue about the 
alternative experiences of minority ethnic groups" She then goes on to provide an example on how people do not understand the alternative experiences of ethnic minorities. She has encountered too many teachers that negate the experience of their students because other students of color have been able to achieve a certain goal or pass a certain test before therefore, they believe that all students of color will be able to do the same. This Color Blindness that many educators continue to use blinds them from giving help that students of color desperately need. Amy put it best: "when you're colorblind you don't have to do anything extra." This leads to Unsupported Learning and a Colorblind Workplace

Unsupported Learning happens when teachers use a colorblind ideology in their classroom. Teachers use their assumptions of students based on their success and/or failures in two ways. First, if a student is successful in their class in an academic way, they will assume that all students with the same background will be able to complete the task as well and will not offer any additional assistance. Additionally, if a student fails in some academic way, they will assume that all students with the same background will fail to accomplish the task and also not offer additional help. This typically occurs to students of color leading to students of color being "left to figure things out on their own." Amy is white passing Latina. This means that Amy can pass as a white person, and because of this she sees examples of this Unsupported Learning all the time. As an English Learner teacher, she has to battle against the pervasive beliefs on how people learn English. She goes on to say:

Even when there is mountains of data in front of the them and research and halfway through the semester, they still say; well I think it's wrong, its pro-immersion or its they must be lazy or I know a person who was 18 years old when he came to the country and he worked 40 hours at night and he did it. 
The belief that one person can accomplish something, means that everyone can accomplish it in the same way is ignorant and harmful. This belief has been pushed onto many educators based on the idea of meritocracy. This idea that hard work pays off, ignores the background of students and their outside experience

Colorblind Workplace occurs when administration handles workplace issues through a colorblind lens. Dana felt the effects of color blindness throughout her entire academic career; as an undergrad student, as a credential student and even at work. "I was left a lot of times and still am even at work, I am left to figure out what to do, instead of having someone to go; this is what you do now, you take the rest and go with it." One experience that she recalls as a teacher was when she had points of contention with three teachers - all white. She voiced her concerns with her principal because she felt that they were not issues that she should be handling on her own. She scheduled a meeting with a Union Representative and her principal. Her principal failed to show up. She felt like because she was Black, the issue wasn't handled. She goes on to tell me, "I felt like a lot of it had to do with here we go here's another Black person again complaining about something." Additionally, I had a similar point of contention with a few of the teachers that Dana had. We had gone to a professional development meeting and the topic of conversation was how to make our campus more culturally responsive. I suggested to the group that we should not police Blacks' students over the use of the N-word in their free time, especially if you are not a Black teacher. This did not sit well with another teacher and she became verbally aggressive about how that word made her feel unsafe and it should not be allowed. However, because my point of contention was displayed in front of multiple people and I was verbally accosted without even saying a word to the other teacher, my issue was resolved quicker. The same colorblind logic applies to issues in the workplace that arise because of race, gender, age, etc. If we pretend 
like it is an issue of differing personalities, rather than addressing the actual issue of race then we don't have to do any extra work. It isn't until it is blatantly shown that issue is one of the -isms (racism, sexism, etc.) that action is taken and by then those discriminated intentionally become silent. The experiences of Teachers of Color then become Dismissed.

This Dismissiveness comes in two ways; Dismissive of Knowledge and Dismissive of Experiences. Dismissiveness of Knowledge stems from others, be it teachers, parents, administration, etc. ignoring the knowledge that Teachers of Color have because of their race. Race coupled with age can make it a bigger challenge to overcome. Joseph, a 24-year-old science teacher, shared his experience of Back to School Night. Every Back to School Night Joseph has to prove that he is capable of teaching science to the parents of his students.

I definitely have felt like some people who are a little a little concerned that I'm the teacher for this student... They don't know the first thing about me, but they're concerned; you can tell from the firmness that their handshake or like the not looking in your eye's kind of thing.... I have a serious face all the time. So, I try to smile, and I like to make a welcoming environment for the students. The students know that it's a cool place to be, you know, so that helps a little bit. But I have experienced, you know, like, some odd questions being asked...this is biology, like, this is a standard course, I hope you took it too, you know, like, just, they want to get to something, but they don't know what it is. So, they asked a stupid question.

Dana also has to prove to people that she is capable of teaching math. When asked what makes her particular subject matter uninviting to People of Color she stated because it is "white and male dominated." She goes on to say it makes it hard to collaborate because she has to prove that she is more than capable of being included in the conversation: 
You have this young Black teacher who is saying, I know a little bit about something and then those who I've seen, who are typically older and white, who are doing like who is this young Black female that thinks she knows what I know.

It becomes an additional hurdle that can lead to Exhaustion. By the time that TOC have proven that they have the knowledge to be in the conversation, they may no longer have the energy to engage in the conversation. They become disillusioned with the idea that they may actually be taken seriously in their profession. While by definition knowledge comes from experiences, they are categorized separately because Dismissiveness of Knowledge is about TOC having to prove they are capable of teaching their subject matter, on the other hand Dismissiveness of Experiences is when the experiences of TOC are ignored because others have not experienced anything similar. This becomes prominent during moments of bringing awareness to issues that ethnic minorities face. For the past couple of years, Carmen has been in charge of rolling out Black History Month for the entire school. 2019's BHM program resulted in a lot of Dismissiveness of Experiences from students, teachers and parents. She asked her students about how the program was going in the advisory class and she states that she received this feedback from one of her students:

A student said, I don't why do we have to do this? I don't want to do this. I got homework. And the teacher said, I don't want to do it either. But they're making me do it. And the fact that a teacher said out of their mouth, that in front of kids where Black students in the room was heartbreaking.

Additionally, after the BHM presentation Carmen received multiple emails from parents upset that the program centered around racism. They stated that the program should focus on the "positive stuff". Carmen describes this experience as, "You're telling me to be quiet because it 
makes you uncomfortable." Furthermore, within this BHM program, they stated that if you are not Black you should not say the "N-word". She had an encounter with one white teacher who came up to her after the program, saying that, "I felt some kind of way about you saying that... because I've used that word, I used to use that word all the time. I grew up using it...She's like, but I have Black friends." This concept of Entitled Uncomfortability is a common experience that POC often have to deal with, many people feel entitled to something because they have done it before regardless of the fact that it may be harmful or hurtful to POC such as cultural appropriation and when they are "called out" on it, they suddenly are the ones that are uncomfortable. Not only was this teacher dismissive of Carmen's experiences but she was attempting to Intentionally Silence her.

Intentional Silencing occurs when white people become uncomfortable when topics about -isms come up. Words like, "it's different" come up as it was the case for Dana. Dana had an experience where a teacher was talking to her in a condescending tone. Dana, instead of having a heated argument, walked out of the room to address the situation at a later time once tensions had come down. She explained to the other teacher how their words made her feel and instead of listening to her perspective, the other teacher acted like they were the victim. Again, the concept of Entitled Uncomfortability occurs here. The other teacher felt entitled to their own feelings, but when they were "called out" all of the sudden they were the ones that were uncomfortable. Both participants made the point that no one goes out with the intention of being racist or hurtful, it's just that people are unaware of their own biases. This stems from a lack of culturally responsive teaching.

Throughout the year, my school district has had multiple staff meetings and Professional Development days centered around what we can do for our students; how can our students be 
successful. Yet, we only had one day that centered around culturally responsive teaching. Since that training, we had no follow through on whether teachers were implementing the strategies in their classroom. Joseph recalls an experience after multiple fights broke out on campus:

I think all the students in the fight were either Latino, or African American. And this we've had like, a few different incidents throughout the year. And to me, that's a sign of something like these kids need, their basic needs are not being met at the school. And we need to do something even if they came to us from like a really messed up background, which happens a lot, but their needs are not being met at the school. We need to do something. I feel like that's going to be met with more friendly, more this more disingenuous ways of connecting with the kids.

Students know when they are being treated differently because of their race, gender, age, etc. However, some teachers are unaware of how they are putting their own views on the students. One teacher later told me that one of the administrators had gone into the classrooms and told students that if they fought on campus again, they would be arrested. The demographics at this site are primarily students of color. This was something that should have not been said to the students as many already have negative feelings about the police. A culturally aware response would have been something along the lines of: Our teachers can no longer step in between fights as it can be a danger to them. Therefore, the police will be called if there is another fight on campus. This way students are aware of the danger that fighting causes to other people and are aware of the consequences. Dana has had similar encounters where she will be in the middle of a staff meeting or even during lunch and she will hear teachers talk about students. However, she says that even though the teachers may have good intentions with what they are saying, "they don't even realize that they are putting their whiteness on it." 
So, what changes should occur to reduce the silencing of TOCs? All participants stated that there needed to be more culturally responsive teaching and communication. As stated before, not only should more culturally responsive pedagogy be offered but there should be follow through on ensuring that teachers are implementing them in their classroom. This type of teaching would ensure that student's culture and background are acknowledged through classroom management, curriculum and relationship building. Furthermore, it was addressed that these movements need to start from the top. Not only should the administration be pushing for this, but they need to implement them in their hiring practices. One interviewee stated that schools need to make sure they are hiring people that have a personal commitment to education, not just because it's a job.

Lastly, academic institutions should not just hire POC because they want to diversify their workforce, but they should hire them because they want to listen to what they had to say. Most of the experiences above address issues of Intentional Silencing, Intentional Censoring, Dismissiveness and Exhaustion. TOC are dealing with all of these issues and yet, because of these as well they are not being heard. When a TOC of color is telling you something that they experienced, it is not the time to insert your opinion. They are sharing because they want someone to hear what they go through on a daily basis and help them make a change. 


\section{Chapter 5: Implications}

While working in the field of education laced with Whiteness and White Supremacy it is easy to see how social constructs can deter POC from pursuing a career in education. TOCs navigate through multiple barriers that have been named in the findings of this research. First and foremost, TOCs navigate through a Colorblind Workplace, which provides the foundations for other themes to become prominent in educational institutions. Colorblind Workplace allows for TOC to experience a form of Exhaustion that leads to Intentional Censoring and Intentional Silencing. Additionally, a Colorblind Workplace allows for TOC's experiences and knowledge to be Dismissed and for SOC to have an Unsupported Learning environment. The data has supported what other research has stated, namely, that we need to listen to our TOC, we need to make a career in education accessible to all, and we need to implement culturally responsive teaching in order to ensure success for our students.

These changes can be made possible but support from all stakeholders is needed. By using CRT 1, 2, and 3 (Delgado \& Stefanic, 1993; Dickenson, 2012; Ladson-Billings, 2019) as well as the Concept of Whiteness (Bryant Moss \& Boudreau, 2015; Green, Sonn \& Matsebula, 2007; Haviland 2008; Williams 2018) and Microaggression (Cardabo, 2013; DiAngelo 2019; Huber \& Solorzano, 2014; Solorzano, Ceja, \& Yosso, 2000) to analyze the data, key similarities arose. With CRT 1, this study criticizes the speed at which equitable changes are happening. We know what needs to be done but it is not occurring. Through storytelling, CRT 2, I was able to demonstrate the injustices and struggles that Teachers of Color battle daily and what changes they wanted to see happen in K-12 education and in Teacher preparation programs. The concept of intersectionality, CRT 3, was extremely prominent within the interviews. Even when the conversation was about race, age and gender were always brought up as another challenge or as 
an added challenge. Finally, the Concept of Whiteness (Bryant Moss \& Boudreau, 2015; Green, Sonn \& Matsebula, 2007; Haviland 2008; Williams 2018) was addressed but it was addressed from the standpoint of POC, not through the observation of white people. This is different because it may come from a standpoint of bias, but overall the participants agreed that most people who benefit from Whiteness can learn to change. They also agreed that when you ignore Whiteness it gives it more power than when you address it, furthermore, it is white people who are the ones in power to change it.

\section{Implications for Literature}

While the topic of equity and diversity is a commonly researched theme, my research provides new terminology that has not been offered previously. The experiences of TOCs within the research were not new experiences for me, being a TOC. However, the naming of the experiences had not been addressed before. This is a powerful tool for future literature. Typically, when TOCs talk about their experiences, the experiences lack defined terminology for identifying the distinctiveness of those experiences. This allows for those experiences to be ignored and whitewashed. These common occurrences happen to multiple TOC, as seen in the interviews of these research participants.

Additionally, there is a Silencing within the literature that occurs without researchers realizing. There were multiple articles about SOCs and their experiences as well as numerical data about TOCs, but little research focused on the actual lived experiences of TOCs. My research adds to this gap in literature because it shares the lived experiences of the research participants to bring attention to what needs to be revitalized. As TOCs we have two viewpoints that bring credibility to our experience. The first, we were SOCs; most of us were the students that were unsupported, silenced and left to our own devices. We know from a student standpoint 
that the education systems' blind spot are our students of color. Second, as TOCs we navigate the educational institutions. We know that school districts want to reduce that achievement gap but are not using resources in a way that will benefit out SOC. TOCs know when the needs of our SOC are not being addressed and we know how to best support our SOCs but are being ignored. These viewpoints can be a valuable resource in helping reduce the academic achievement gap between our students.

\section{Implications for Practice and Policy}

In naming these themes, we can now have the challenging conversations to end a Colorblind Workplace. These experiences are consistent and happen to many POC. Conversations about race are difficult to have but they can happen in a way where all parties involved learn something new. At the classroom level, simply understanding our own biases and stereotypes is the first step. The more we are aware that our own lived experiences are not the same for everyone, we can move forward toward creating a more culturally responsive classroom and work environment. One important thing to understand is when a TOC comes to a teacher expressing concerns about SOC, it is not a personal attack but rather that the student felt comfortable enough to express the challenges with a teacher to remedy a situation. As teachers, we are here to educate, and we cannot do that properly if we do not educate ourselves first.

When it comes to school, district or state level changes, it will be important to offer more culturally responsive teaching opportunities for our educators. Teacher Preparation Programs vary in how they educate teachers about diversity, equity and culturally responsive teaching, some programs may not even offer classes that cover those topics, so having professional development that centers around those topics will ensure that all teachers have a similar understanding. Therefore, the burden of being a token minority is no longer on the TOCs but a 
school wide effort to combat inequality, inequity, stereotypes and biases. Some forms of culturally responsive teaching can include how to address internal and external biases, how to make curriculum equitable and culturally appropriate or how to understand cultural social norms among students' demographics. There are many available resources that can fit these themes that school districts can implement.

By implementing these changes, SOCs and disadvantaged students will no longer feel like school is unwelcoming or impossible. TOCs will no longer feel like they are tackling systemic racism alone.

\section{Limitations of the Study}

The data sample for this study was small. Participants of this study were primarily African American; two female and two males, one Latinx woman. The study is also limited to one school site. This study's geographic location in Northern California also limits the perspectives.

\section{Implications for Future Research}

In order to understand what other factors could contribute to the lack of teachers, future studies should target different schools, with different racial, social and economic backgrounds to fully understand the experiences of TOCs across the field of education in California. Additionally, the perspectives of students of color should be added to understand the impact that TOCs have on students. SOCs can also add the perspective of why they would or would not pursue a career in education. This potential data could be useful for Teacher Preparation Programs as they can see what might deter SOC from applying. Additionally, numerical data based on how many POC participate, graduate or complete Teacher Preparation Programs should be incorporated as well as looking into Teacher Preparation Programs and what support and 
training are they providing to their student teachers so they can successfully teach in a diverse setting. This data can help Teacher Preparation Programs change the way they are recruiting or accepting teachers and know what type of aid SOC need to be successful in their programs. The findings can serve as tool to complete these future studies. The naming of the experiences gives future research stepping stone into the experiences of POC, SOC and TOC. They can also be a helpful tool to analyze internal biases and stereotypes in school sites, classrooms, researchers and teachers. Most importantly, we need a variety of participants in future research with different backgrounds such as race, ethnicity, age, gender, etc. POC are not free from their own biases about other POC. Additionally, not all experiences of POC are the same, and many different aspects of culture come into play in the lives of teachers. By doing so, we can combat the systemic racism in the field of education and ensure that the diversity we see in our student population is represented in their teachers. 


\section{References}

American Indians/Alaska Natives: Education Issues. (n.d.). Retrieved from http://www.nea.org/home/15596.htm

Andrews, D. J. C., Castro, E., Cho, C. L., Petchauer, E., Richmond, G., \& Floden, R. (2018). Changing the Narrative on Diversifying the Teaching Workforce: A Look at Historical and Contemporary Factors That Inform Recruitment and Retention of Teachers of Color. Journal of Teacher Education, 70(1), 6-12. https://doi.org/10.1177/0022487118812418

Baker, G. C. (1993). Planning and Organizing for Multicultural Instruction. Second Edition. Addison Wesley Distribution Center.

Bastard Fairy Films. (2006). The Canary Effect

Boone, K., \& Bellwether Education Partners. (2018, December 13). America Has Always Used Schools as a Weapon Against Native Americans. Retrieved from https://educationpost.org/america-has-always-used-schools-as-a-weapon-againstnative americans $/$

Bryant, L. C., Moss, G., \& Boudreau, A. Z. (2015). Race Dialogue in Teacher Preparation: Beginning the Conversation. International Journal of Critical Pedagogy, 6(2), 43-60

Carr, Paul. (2006). Social Justice and Whiteness in Education: Color-blind Policymaking and Racism. Journal for Critical Educational Policy Studies. 4 (2), 297-329

Carr, P. R., \& Klassen, T. R. (1997). Different Perceptions of Race in Education: Racial Minority and White Teachers. Canadian Journal of Education / Revue Canadienne De Léducation, 22(1), 67. https://doi.org/10.2307/1585812 
Clarren, R. (2017, August 14). How America Is Failing Native American Students. Retrieved from https://www.thenation.com/article/archive/left-behind/

Conwright, A. (2019, October 24). When We Ask African American Teachers to

Discipline African American Students Because They're African American. Retrieved from https:/www.teachthought.com/education/when-we-ask-african-american-teacherstodiscipline-african-american-students-students-because-theyre-african-american/

Creswell, J. W., \& Creswell, J. D. (2018). Research design: Qualitative, quantitative, and mixed methods approaches. Thousand Oaks, CA: SAGE Publications.

DiAngelo, R. J. (2016). What does it mean to be white?: developing white racial literacy. New York: Peter Lang.

DiAngelo, R. J. (2019). White fragility: why it's so hard for white people to talk about racism. London: Allen Lane, an imprint of Penguin Books.

Dickinson, E. (2012). Addressing Environmental Racism Through Storytelling: Toward an Environmental Justice Narrative Framework. Communication, Culture \& Critique, 5(1), 57-74. https://doi.org/10.1111/j.1753-9137.2012.01119.

Delgado, R., \& Stefancic, J. (2012) Critical Race Theory: An Introduction. Critical America (2nd ed.). New York University Press.

Delgado, R., \& Stefancic, J. (1993). Critical Race Theory: An Annotated Bibliography. Virginia Law Review, 79(2), 461. https://doi.org/10.2307/1073418

Green, M. J., Sonn, C. C., \& Matsebula, J. (2007). Reviewing Whiteness: Theory, Research, and Possibilities. South African Journal of Psychology, 37(3), 389-419. https://doi.org/ 10.1177/008124630703700301 
Gomez, M. L. (2014). Examining Discourses of an Aspiring Teacher of Color in the Figured World of Schooling. Teacher Education Quarterly, 45-62.

Haviland, V. S. (2008). “Things Get Glossed Over” Rearticulating the silencing power of whiteness in education. Journal of Teacher Education, 59(1), 40-54. https://doi.org/10.1177/002248710731075

Hayes, C., \& Fashing-Varner, K. J. (2015). Racism 2.0 and the Death of Social and Cultural Foundations of Education: A Critical Conversation. Educational Foundations, 103-120.

Huber, L. P., \& Solorzano, D. G. (2014). Racial microaggressions as a tool for critical race research. Race Ethnicity and Education, 18(3), 297-320. https://doi.org/10.1080/13613324.2014.994173

Huerta, G. (2009). Educational foundations: diverse histories, diverse perspectives. Boston, MA:Houghton Mifflin.

Irvine, J. J., \& Fenwick, L. T. (2011). Teachers and Teaching for the New Millennium: The Role of HBCUs. Journal of Negro Education, 80(3), 197-208.

Jayapal, S. (1987). School Desegregation and White Flight: The Unconstitutionality of Integration Maintenance Plans. University of Chicago Legal Forum, 1987(1), 389409.

Jackson, T. O., \& Kohli, R. (2016). Guest Editors; Introduction: The State of Teachers of Color. Equity \&amp; Excellence in Education, 49(1), 1-8.

Kirp, D. L. (1979). Race, Schooling, and Interest Politics: The Oakland Story. The School Review, 87(4), 355-397. https://doi.org/10.1086/443492 
Kohli, R. (2018). Lessons for Teacher Education: The Role of Critical Professional Development in Teacher of Color Retention. Journal of Teacher Education, 70(1), 3950. https://doi.org/10.1177/0022487118767645

Kimberlé Crenshaw on Intersectionality, More than Two Decades Later. (2017.). Retrieved from https:/www.law.columbia.edu/pt-br/news/2017/06/kimberle-crenshawintersectionality

Ladson-Billings, G. (2019). Just What Is Critical Race Theory, and What's It Doing in a Nice Field Like Education? Race Is ... Race Isn't, 7-30. https://doi.org/10.4324/9780429503504-2

Leonardo, Z. (2007). The war on schools: NCLB, nation creation and the educational construction of whiteness. Race Ethnicity and Education, 10(3), 261-278. https://doi.org/10.1080/13613320701503249

Loewen, J.W. (1995). Lies My Teacher Told Me Everything Your American History Textbook Got Wrong. New York: New York, Touchstone

MacDonald, V. M. (n.d.). Demanding their Rights: The Latino Struggle for Educational Access and Equity. Retrieved December 7, 2019, from https://www.nps.gov/heritageinitiatives/latino/latinothemestudy/education.htm.

Matias, C. E., Montoya, R., \& Nishi, N. W. M. (2016). Blocking CRT: How the Emotionality of Whiteness Blocks CRT in Urban Teacher Education. Educational Studies, 52(1), 1-19. https://doi.org/10.1080/00131946.2015.1120205

Maxwell, J. A. (2013). Qualitative research design an interactive approach. Thousand Oaks (Calif.): SAGE Publications. 
Menchaca, M., \& Valencia, R. R. (1990). Anglo-Saxon Ideologies in the 1920s-1930s:

Their Impact on the Segregation of Mexican Students in California. Anthropology \&Education Quarterly, 21(3), 222-249. https://doi.org/10.1525/aeq.1990.21.3.04x0607i

Ortiz, V., \& Telles, E. (2012). Racial Identity and Racial Treatment of Mexican Americans. Race and Social Problems, 4(1), 41-56. https://doi.org/10.1007/s12552-012-9064-8

Overview of Baltimore, Maryland (City). (n.d.). Retrieved from https://statisticalatlas.com/place/Maryland/Baltimore/Overview

Patton, L. D. (2015). Disrupting Postsecondary Prose: Toward a Critical Race Theory of Higher Education. Urban Education, 51(3), 315-342. https://doi.org/10.1177/0042085915602542

Pribanic-Smith, E. J. (2015). American Latinos and the Making of the United States: A Theme Study. American Journalism, 32(2), 248-250. https://doi.org/10.1080/08821127.2015.1036699

Renzulli, L. A., \& Evans, L. (2005). School Choice, Charter Schools, and White Flight. Social Problems, 52(3), 398-418. https://doi.org/10.1525/sp.2005.52.3.398

Rogers-Ard, R., Knaus, C. B., Epstein, K. K., \& Mayfield, K. (2012). Racial Diversity Sounds Nice; Systems Transformation? Not So Much. Urban Education, 48(3), 451-479.

Rossell, C. H. (1975). School Desegregation and White Flight. Political Science Quarterly, 90(4), 675. https://doi.org/10.2307/2148750

Solorzano, D., Ceja, M., \& Yosso, T. (2000). Critical Race Theory, Racial Microaggressions, and Campus Racial Climate: The Experiences of African American College Students. The Journal of Negro Education, 69(1), 60-73. 
Veloria, C. N. (2015). “Maybe This Is Because Society?”: Discourses of Race in the Context of a Service-Learning Project. Humanity \& Society, 39(2), 135-155.

Williams, T. M. (2018). When Will We Listen and Heed: Learning from Black Teachers to Understand the Urgent Need for Change. The Western Journal of Black Studies, 42(1 \& 2), 3-17. 
Appendix A: Interview Questions 


\section{Demographics:}

What is your race?

What is your ethnicity?

What is your age?

What do you teach?

\section{General Questions for experience while getting credentialed:}

Did your race help or hinder you in your journey?

Did your economic standpoint help or hinder you?

When you finally achieved your goal how did you feel?

How did you see your race after you achieved your goal?

Do you believe the field of education is inviting to people of color?

If you are credentialed, what would you have wanted done differently in your teacher preparation program?

If you are not credentialed, what would you want your teacher preparation program to change?

Do you think your particular subject matter is open to teachers of color? Why or why not?

\section{Experience as a student of color:}

From your experience with teacher that taught you, did you see a difference in the teaching style between white teachers and teachers of color?

How did you feel as a student around white teachers?

How did you feel as a student around teachers of color?

\section{Questions teacher of color experience:}

How do you feel as a teacher around white teachers?

How do you feel as a teacher around teachers of color? 
What is your experience working with teachers of color?

What is your experience working with white teachers?

What is your experience being a teacher of color?

What are some of the challenges of being a teacher of color?

What are some of the benefits of being a teacher of color?

\section{Questions about Whiteness Supremacy \& Race:}

What are your thoughts on White supremacy, White fragility, and white privilege?

What do you think needs to be done to address these issues in education?

Do you experience color having correlation to power? If so, how?

Can you tell me of a time when you felt you could not speak up to admin or someone in power because of your race?

Can you tell me of a time when you had to deal with whiteness, be it white privilege, white fragility, white supremacy or all of them, in education?

What is your take on colorblindness?

Do you believe that students of color respond better to teachers of color?

What do you want your white counterparts to understand about your experience being a teacher of color?

What types of microaggressions have you experienced through the process of becoming a teacher?

What types of microaggressions have you experienced once you became a teacher?

Can you tell me of a time that you felt that you were mistreated or disrespected because of your race as a teacher?

\section{Final Questions and request:}


Anything that you would like to add that was not addressed within the questions?

Could you please write down any thoughts that you may have after this interview, so we could discuss at a later date? 
Appendix B: IRB Approval 


\section{DOMINICAN \\ UNIVERSITY \\ of CALIFORNIA}

$1 / 16 / 20$

Stephany Vallejo

50 Acacia Ave.

San Rafael, CA 94901

Dear Stephany,

On behalf of the Dominican University of California Institutional Review Board for the Protection of Human Participants, I am pleased to approve your proposal entitled How Whiteness Blocks Teachers of Color in the field of Education (IRBPHP IRB Application \#10863).

In your final report or paper please indicate that your project was approved by the IRBPHP and indicate the identification number.

I wish you well in your very interesting research effort.

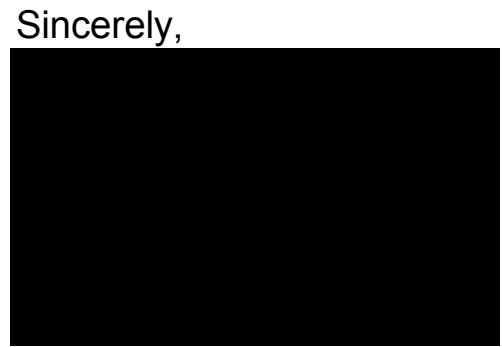

Randall Hall, Ph.D.

Chair, IRBPHP

Cc: Matthew E. Davis, Ph.D.

Institutional Review Board for the Protection of Human Participants

Office of Academic Affairs • 50 Acacia Avenue, San Rafael, California 95901-2298 • 415-257-

1310 www.dominican.edu 